\title{
PENGARUH RENDAM AIR HANGAT PADA KAKI TERHADAP INSOMNIA PADA LANSIA DI DESA TENGAH KECAMATAN PANTAI LABU KABUPATEN DELI SERDANG TAHUN 2018
}

\author{
Mestika Rija Helti ${ }^{1}$, Dedi ${ }^{2}$
}

STIKes Rumah Sakit Haji Medan, Indonesia

Article Info

Keywords:

Warm Soak

Insomnia

Elderly

\begin{abstract}
Insomnia is a symptom experienced by clients when they experience chronic sleep difficulties, often waking up from sleep, and or short sleep or non-restorative sleep. Handling of insomnia in the elderly can be done with pharmacological and non pharmacological. One type of treatment of non-pharmacological insomnia in the elderly is soaking the feet with warm water. Soaking warm water on the feet is a sleep stimulation technique that is done by soaking the feet in warm water with a temperature of $37^{\circ} \mathrm{C}-39^{\circ} \mathrm{C}$. This study aims to determine the effect of warm water soak on the feet against insomnia in the elderly in Desa Tengah District Labu Beach, Deli Serdang Regency. This study uses a quasi-experimental type using one group pretest and posttest desaign methods. The population in this study were all elderly people in the Middle Village of hamlet I and hamlet II with ages above 60-74 years. The population obtained was 53 elderly. The sampling technique is done by using non-probability sampling method with purposive sampling technique obtained as many as 20 people. Analysis of the data used in this study is paired t-test. Hypothesis test results indicated by using paired t-test is a sig value of $0.000(<0.05)$. This shows that there is an effect of warm water soak on the feet against insomnia in the elderly in Central Village Pantai Labu Subdistrict Deli Serdang Regency in 2018. The conclusion in this study is that there is an effect of warm water soak on the feet against insomnia in the elderly in the Central Village Pantai Labu District Deli Serdang 2018. Soaking feet with warm water can be used as an alternative measure to reduce insomnia and as a reference in efforts to improve the health of the elderly.
\end{abstract}

This is an open access article under the CC BY-SAlicense.

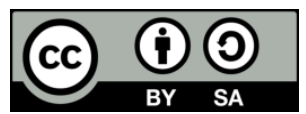

\section{Corresponding Author:}

Mestika Rija Helti,

Program Studi D-III Kebidanan,

STIKes Rumah Sakit Haji Medan,

Jl. Rumah Sakit H., Medan Estate, Kec. Percut Sei Tuan, Kabupaten Deli Serdang, Medan-Sumatera Utara.

Email: mestikarija1@gmail.com 


\section{INTRODUCTION}

World Health Organisation (WHO), lansia adalah seseorang yang telah memasuki usia 60 tahun keatas. Lansia merupakan kelompok umur pada manusia yang telah memasuki tahapan akhir dari fase kehidupannya. Kelompok yang dikategorikan lansia ini akan terjadi suatu proses yang disebut Aging Process atau proses penuaan. Proses penuaan adalah siklus kehidupan yang ditandai dengan tahapan-tahapan menurunnya berbagai fungsi organ tubuh, yang ditandai dengan semakin rentannya tubuh terhadap berbagai serangan penyakit yang dapat menyebabkan kematian misalnya pada sistem kardiovaskuler dan pembuluh darah, pernafasan, pencernaan, endokrin dan lain sebagainya. Batasan -batasan lanjut usia meliputi empat tahapan yaitu (1) lanjut usia (elderly) 60-74 tahun, (2) lanjut usia tua (old) 75- 90 tahun, (3) dan usia sangat tua (very old) di atas usia 90 tahun.

Berdasarkan data United Nation Departement of Economic and Social Affairs menyatakan bahwa jumlah penduduk yang berusia lebih dari 60 tahun pada tahun 2015 adalah sebesar $12,3 \%$ dari total populasi dunia, dan diprediksikan tahun 2020 sebesar 13,5\%, tahun 2025 sebesar 14,9\%, dan pada tahun 2030 sebesar 16,4\%. Dari data tersebut dapat dilihat bahwa dari tahun 2015 - 2030 jumlah lansia yang ada di dunia mengalami peningkatan di setiap tahunnya. (Kementerian Kesehatan RI, 2017)

Data Badan Pusat Statistik menunjukkan bahwa penduduk lansia di Indonesia pada tahun 2000 sebanyak 14.439.967 jiwa (7,18 persen dari jumlah keseluruhan penduduk Indonesia), selanjutnya pada tahun 2010 meningkat menjadi 23.992 .553 jiwa (9,77 persen dari jumlah keseluruhan penduduk Indonesia). Pada tahun 2020 diprediksikan jumlah lansia mencapai 28.822.879 jiwa (11,34 persen dari jumlah keseluruhan penduduk Indonesia) (Badan Pusat Statisik Indonesia, 2012). Jumlah tersebut menempatkan Indonesia pada urutan ketiga dari negara-negara Asia dengan jumlah lansia terbesar setelah Cina dan India (Kementerian Kesehatan RI, 2013).

Proses menua (aging) adalah suatu proses alami yang disertai dengan adanya penurunan kondisi fisik serta penurunan fungsi organ tubuh. Hal ini juga diikuti dengan perubahan emosi secara psikologis dan kemunduran kognitif. Hal-hal lain yang juga sering muncul pada lansia seperti kecemasan yang berlebihan, kepercayaan diri menurun, insomnia, semuanya saling berinteraksi satu sama lain. Keadaan tersebut cenderung berpotensi menimbulkan masalah gangguan tidur pada lansia (Setyaningtyas, 2014).

Adapun gangguan masalah tidur yang sering dialami lansia berupa susah tidur pulas, sering terbangun di malam hari dan sulit memulai tidur kembali, berkurangnya waktu tidur malam, semakin panjangnya waktu yang dibutuhkan untuk jatuh tidur (sleep latency), perasaan tidur yang kurang, terbangun cepat dan tidur sekejap pada siang hari (naps) sering terjadi berulang dan tidak disadari.

Salah satu terapi relaksasi adalah dengan menggunakan air. Hydro therapy adalah penggunaan air untuk menyembuhkan dan meringankan berbagai keluhan. Untuk tujuan ini, air bias digunakan dalam banyak cara dan kemampuannya sudah diakui sejak dahulu, terutama di kerajaan Yunani, kekaisaran Romawi dan Kebudayaan Turki juga oleh masyarakat Eropa dan Tiongkok kuno. Masyarakat umum juga menyadari bahwa manfaat air hangat adalah untuk membuat tubuh lebih rileks, menyingkirkan rasa pegal-pegal dan kaku di otot, dan mengantar agar tidur bisa lebih nyenyak (Sustrani, Alam, Hadibroto, 2006).

Hasil survei pendahuluan yang dilakukan oleh Andrian (2016) pada bulan November di Panti Werda Dharma Bakti Pajang Surakarta bahwa jumlah lansia yang tinggal saat ini berjumlah 83 Lansia dan Griya PMI Peduli Surakarta berjumlah 25 lansia. Hasil wawancara yang dilakukan peneliti di Panti Werda Dharma Bakti Pajang Surakarta terhadap 15 lansia didapatkan 13 lansia yang mengalami gangguan tidur dan di Griya PMI Peduli Surakarta terhadap 10 lansia didapatkan 9 lansia yang mengalami gangguan tidur.

Gangguan tidur yang dialami oleh para lansia tersebut seperti kesulitan untuk tidur, sering terbangun pada malam hari, dan kesulitan untuk tidur kembali. Upaya yang dilakukan oleh petugas kesehatan tersebut dalam menangani insomnia adalah dengan pemberian obat tidur atau terapi farmakologis, sedangkan pemberian terapi farmakologis dalam waktu lama dapat memberikan efek yang tidak baik bagi kesehatan lansia yaitu seperti gangguan koordinasi berpikir, gangguan fungsi mental, amnesia anterograd, ketergantungan dan bersifat racun. Petugas kesehatan tersebut belum pernah memberikan pengobatan secara non farmakologis seperti masase kaki dan rendam air hangat pada kaki.

\section{RESEARCH METHOD}

Penelitian ini menggunakan jenis quasi eksperimen dengan menggunakan metode one group pretest and posttest desaign. Populasi dalam penelitian ini adalah seluruh lansia yang berada di Desa Tengah dusun I dan dusun II dengan usia diatas 60-74 tahun. Jumlah populasi yang didapatkan yaitu sebanyak 53 lansia. Teknik pengambilan sampel dilakukan dengan menggunakan cara non probability sampling dengan teknik purposive sampling didapatkan sebanyak 20 orang. Analisa data yang digunakan dalam penelitian ini adalah uji paired t-test. 


\section{RESULTS AND ANALYSIS}

\subsection{Hasil}

Tabel 1. Distribusi Frekuensi Dan Persentase Karakteristik RespondenYang Mengalami Insomnia Di Desa Tengah Kecamatan Pantai Labu Kabupaten Deli Serdang Tahun 2018

\begin{tabular}{|c|c|c|c|}
\hline No & Karakteristik responden & Frekuensi & Persentase \% \\
\hline \multirow[t]{4}{*}{1} & Jenis kelamin & & \\
\hline & Laki-laki & 7 & $35,0 \%$ \\
\hline & Perempuan & 13 & $65,0 \%$ \\
\hline & Total & 20 & $100 \%$ \\
\hline \multirow[t]{5}{*}{2} & Umur (tahun) & & \\
\hline & $60-64$ & 8 & $40,0 \%$ \\
\hline & $65-69$ & 5 & $25,0 \%$ \\
\hline & $70-74$ & 7 & $35,0 \%$ \\
\hline & Total & 20 & $100 \%$ \\
\hline
\end{tabular}

Berdasarkan tabel diatas dapat dilihat bahwa mayoritas jenis kelamin responden adalah perempuan sebanyak 13 orang $(65,0 \%)$, dan distribusi umur responden menunjukkan bahwa kisaran umur responden yang paling tinggi adalah umur 60-64 (40,0\%).

Tabel 2. Distribusi Frekuensi Tingkatan Insomnia Sebelum Dilakukan Rendam Air Hangat Pada Kaki Terhadap Insomnia Pada Lansia Di Desa Tengah Kecamatan Pantai Labu Kabupaten Deli Serdang Tahun

\begin{tabular}{ccc} 
& 2018 & \\
\hline Tingkatan Insomnia & Frekuensi & Persentase \\
\hline Tidak Insomnia & 0 & $0 \%$ \\
Ringan & 7 & $35,0 \%$ \\
Sedang & 10 & $50,0 \%$ \\
Berat & 3 & $15,0 \%$ \\
\hline Total & $\mathbf{2 0}$ & $\mathbf{1 0 0 \%}$
\end{tabular}

Berdasarkan tabel diatas tingkatan insomnia sebelum dilakukan rendam air hangat pada kaki mayoritas sedang sebanyak 10 orang $(50,0 \%)$.

Tabel 3. Distribusi Frekuensi Tingkatan Insomnia Sesudah Dilakukan Rendam Air Hangat Pada Kaki Terhadap Insomnia Pada Lansia Di Desa Tengah Kecamatan Pantai Labu Kabupaten Deli Serdang Tahun

\begin{tabular}{ccc} 
& 2018 & \\
\hline Tingkatan Insomnia & Frekuensi & Persentase \\
\hline Tidak Insomnia & 6 & $30,0 \%$ \\
Ringan & 10 & $50,0 \%$ \\
Sedang & 4 & $20,0 \%$ \\
Berat & 0 & $0 \%$ \\
\hline Total & $\mathbf{2 0}$ & $\mathbf{1 0 0 \%}$
\end{tabular}

Berdasarkan tabel diatas tingkatan insomnia sesudah dilakukan rendam air hangat pada kaki mayoritas ringan sebanyak 10 orang $(50,0 \%)$.

Tabel 4. Pengaruh Rendam Air Hangat Pada Kaki Terhadap Insomnia Pada Lansia Di Desa Tengah Kecamatan Pantai Labu Kabupaten Deli Serdang Tahun 2018

\begin{tabular}{ccccccc}
\hline Variabel & Mean & $\begin{array}{c}\text { Rata-rata } \\
\text { Penurunan }\end{array}$ & Std. Dev & $\mathbf{P}$ & $\mathbf{T}$ & $\mathbf{N}$ \\
\hline pretest & 14.65 & 3.900 & 3.376 & 000 & 18.020 & 20 \\
\hline posttest & 10.75 & & 3.739 & & & \\
\hline
\end{tabular}

Analisa data mengenai pengaruh rendam air hangat pada kaki terhadap insomnia pada lansia Di Desa Tengah Kecamatan Pantai Labu Kabupaten Deli Serdang Tahun 2018, dalam penelitian ini menggunakan uji paired sample $\mathrm{T}$ test yaitu tingkatan insomnia rata-rata (Mean) sebelum rendam air hangat pada kaki 14.65, dan sesudah rendam air hangat pada kaki 10.75, maka didapatkan nilai rata-rata penurunan 3.900 dan nilai $\mathrm{p}$-value $=0.000$ dengan $(<0,05)$, dengan nilai $\mathrm{t}=18.020$, dengan demikian hipotesis penelitian diterima bahwa ada pengaruh rendam air hangat pada kaki terhadap insomnia pada lansia Di Desa Tengah Kecamatan Pantai Labu Kabupaten Deli Serdang Tahun 2018. 


\subsection{Pembahasan}

\section{Tingkatan Insomnia Sebelum Dilakukan Rendam Air Hangat Pada Kaki Pada Lansia Di Desa Tengah} Kecamatan Pantai Labu Kabupaten Deli Serdang Tahun 2018.

Berdasarkan penelitian yang telah dilakukan di Desa Tengah Kecamatan Pantai Labu Kabupaten Deli Serdang Tahun 2018 didapatkan mayoritas tingkatan insomnia responden sebelum rendam air hangat pada kaki adalah insomnia sedang sebanyak 10 orang. Responden yang mangalami insomnia terjadi pada responden yang mayoritas berumur 60-64 tahun sebanyak 8 orang. Menurut penelitian McCall (2012) bahwa pasien usia lanjut lebih cenderung menderita insomnia yang ditandai dengan kesulitan mempertahankan tidur daripada kesulitan memulai tidur.

Faktor-faktor yang mempengaruhi insomnia pada lansia antara lain proses penuaan, gangguan psikologis, gangguan medis umum, gaya hidup, faktor lingkungan fisik, dan faktor lingkungan sosial (Rafknowledge dalam Prananto, 2016).

Titis Utami (2015) juga pernah melakukan penelitian tentang Pengaruh Rendam Air Hangat Pada Kaki Terhadap Insomnia Pada Lansia Di Panti Sosial Tresna Werdha Yogyakarta Unit Budi Luhur pada tanggal 30 September 2014 terhadap 88 lansia. Penelitian tersebut menyatakan bahwa terdapat 40 orang yang mengalami gangguan tidur. Gejala yang sering dialami yaitu sering terbangun dimalam hari dan sulit tidur kembali, dan ada yang sulit memulai tidur hingga larut malam. Intervensi yang selama ini dilakukan berupa pemberian nutrisi, memberikan posisi tidur yang nyaman dan memberikan bacaan. Namun dengan intervensi tersebut ternyata belum berhasil mengatasi gangguan tidur yang dialami lansia. Berdasarkan wawancara petugas panti lansia yang mengalami kesulitan tidur langsung diberikan obat CTM untuk mengatasinya.

\section{Tingkatan Insomnia Sesudah Dilakukan Rendam Air Hangat Pada Kaki Pada Lansia Di Desa Tengah Kecamatan Pantai Labu Kabupaten Deli Serdang Tahun 2018.}

Berdasarkan penelitian yang telah dilakukan di Desa Tengah Kecamatan Pantai Labu Kabupaten Deli Serdang Tahun 2018 didapatkan mayoritas tingkatan insomnia responden sesudahrendam air hangat pada kaki adalah insomnia ringan sebanyak 10 orang.

Menurut Guyton (2007) menyatakan bahwa rasa hangat yang langsung menyentuh kulit yang terdapat banyak pembuluh darah memberikan efek relaksasi sehingga endorphin dilepaskan menyebabkan rasa rileks.Air hangat memberikan efek sedasi yang dapat merangsang tidur. Merendam kaki dalam air hangat yang bertemperatur $37^{\circ} \mathrm{C}-39^{\circ} \mathrm{C}$ akan memberikan efek sopartifik (efek ingin tidur) dan dapat mengatasi gangguan tidur. Secara fisiologi didaerah kaki terdapat banyak syaraf terutama dikulit flexus venous dari rangkaian ini stimulasi diteruskan ke kornu posterior kemudian dilanjutkan ke medulla spinalis, dari sini diteruskan ke lamina, I, II, III radiksdorsalis, selanjutnya ke ventro basal thalamus dan masuk ke batang otak tepatnya didaerah rafe bagian bawah pons dan medulla disinilah terjadi efek soparifik (ingin tidur).

\section{Pengaruh Rendam Air Hangat Pada Kaki Terhadap Insomnia Pada Lansia Di Desa Tengah Kecamatan Pantai Labu Kabupaten Deli Serdang Tahun 2018.}

Dari data hasil penelitian yang telah dilakukan peneliti terhadap 20 orang responden. Rata-rata tingkatan insomnia sebelum rendam air hangat pada kaki dengan mean 14.65 dan nilai rata-rata (mean) sesudah intervensi 10.75 maka didapatkan nilai rata-rata penurunan 3.900 dengan nilai std. Deviasi tingkat insomnia 18.020 diperoleh nilai p-value sebesar 0.000 karena p-value $(0.000<0.05)$ oleh sebab itu dapat disimpulkan ada pengaruh rendam air hangat pada kaki terhadap insomnia pada lansia Di Desa Tengah Kecamatan Pantai Labu Kabupaten Deli Serdang Tahun 2018.

Widya (2010) mengemukakan penanganan gangguan tidur dapat dilakukan dengan 2 cara yaitu secara farmakologi dan secara non farmakologi. Secara farmakologi yaitu dengan memberikan obat sedative hipnotik seperti golongan benzodiazepine (ativan, valium, dan diazepam). Namun, pada lansia terjadi perubahan farmako dinamik, farmako kinetik serta metabolisme obat dalam tubuh lansia yang menyebabkan penatalaksanaan dengan farmakologis sangat memberi risiko pada lansia. Dengan demikian penatalaksanaan secara non farmakologi adalah pilihan alternative yang lebih aman, yakni dengan cara terapi stimulus control, melakukan olah raga ringan, berjalan kaki pada pagi hari, berlari-lari kecil, senam atau sekedar peragangan otot, terapi relaksasi (Putra, 2011).

Banyak cara yang dapat digunakan untuk menanggulangi masalah tidur. Salah satunya adalah terapi relaksasi yang termasuk terapi nonfarmakologi. Terapi relaksasi seperti rendam kaki dengan air hangat dapat dilakukan untuk jangka waktu yang terbatas dan biasanya tidak memiliki efek samping. Rasa hangat yang langsung menyentuh kulit yang terdapat banyak pembuluh darah memberikan efek relaksasi sehingga endorphin dilepaskan menyebabkan rasa rileks. Air hangat memberikan efek sedasi yang dapat merangsang tidur. Merendam kaki dalam air hangat yang bertemperatur $37-40^{\circ} \mathrm{C}$ akan menimbulkan efek sopartifik (ingin tidur) dan mengatasi gangguan tidur (Wijayanti, 2009). 


\section{CONCLUSION}

Kesimpulan dalam penelitian ini adalah ada pengaruh rendam air hangat pada kaki terhadap insomnia pada lansia di Desa Tengah Kecamatan Pantai Labu Kabupaten Deli Serdang Tahun 2018. Rendam kaki dengan air hangat dapat digunakan sebagai salah satu alternatif tindakan untuk mengurangi insomnia dan sebagai acuan dalam upaya peningkatan kesehatan lansia.

\section{REFERENCES}

Azizah, L. M, (2011). Keperawatan Lanjut Usia. Yogyakarta: Graha Ilmu.

Bandiyah, S. 2017. Lanjut Usia (Lansia) Dan Keperawatan Gerontik. Yogyakarta: Nuha Medika.

Dewi, PA. 2013. Angka Kejadian serta Faktor-Faktor yang Mempengaruhi Gangguan Tidur (Insomnia) Pada Lansia di Panti Sosial Tresna Werdha Wana Seraya Denpasar Bali.

Dinas Kesehatan. 2014. Manfaat dan Kerugian Air Hangat. Diakses dari http://dinkes.jogjaprov.go.id/berita/detil_berita/623-dibalik-manfaat-ada-rugi-mandi-air-hangat pada tanggal 19 Januari 2014

Fatimah. Merawat Manusia Lanjut Usia Suatu Pendekatan Proses Keperawatan Gerontik. Jakarta : TIM, 2010.

Guyton and Hall. 2010. Textbook of Medical Physiology, 12 ${ }^{\text {th }}$ ed. Jakarta: EGC.

Khasanah. K, 2012. Kualitas Tidur Lansia di Balai Rehabilitasi Sosial Semarang. ejournals1.undip.ac.id.1 (1).189-196 : Semarang.

Khotimah. 2012. Pengaruh Rendam Air Hangat Pada Kaki Dalam Meningkatkan Kuantitas Tidur Lansia. Skripisi, Universitas Pesantren Tinggi Darul Ulum Jombang.

Ningrum, Destiana A. 2012. Perbandingan Metode Hydrotherapy Massage dan Massage Manual Terhadap Pemulihan Kelelahan Pasca Olahraga Anaerobic Lactacid. Bandung; Repository.UPI.Edu.

Nursalam, 2011. Konsep Dan Penerapan Metodologi Penelitian Ilmu Keperawatan: Pedoman Skripsi, Tesis Dan Instrument Penelitian Keperawatan. Jakarta: Salemba Medika.

Padila. 2013. Keperawatan Gerontik. Yogyakarta: Nuha Medika.

Potter, P.A \& Perry, (2010). Fundamental Keperawatan. Edisi 7. Vol 2, Jakarta: Salemba Medika.

Priyoto. 2015. Nursing Intervention Classification (NIC) Dalam Keperawatan Gerontik. Jakarta: Salemba Medika. 